\title{
Race, insurance type, and stage of presentation among lung cancer patients
}

\author{
Jimmy T Efird ${ }^{1,2^{*}}$, Hope Landrine ${ }^{1}$, Kristin Y Shiue ${ }^{1}$, Wesley $\mathrm{T}^{\prime} \mathrm{N}^{\prime} \mathrm{Neal}^{3}$, Tarun Podder $^{4}$, Julian G Rosenman ${ }^{5}$ \\ and Tithi Biswas ${ }^{4}$
}

\begin{abstract}
The purpose of this study was to determine whether African-American lung cancer patients are diagnosed at a later stage than white patients, regardless of insurance type. The relationship between race and stage at diagnosis by insurance type was assessed using a Poisson regression model, with relative risk as the measure of association. The setting of the study was a large tertiary care cancer center located in the southeastern United States. Patients who were diagnosed with lung cancer between 2001 and 2010 were included in the study. A total of 717 (31\%) African-American and 1,634 (69\%) white lung cancer patients were treated at our facility during the study period. Adjusting for age, sex, and smoking-related histology, African-American patients were diagnosed at a statistically significant later stage (III/IV versus I/II) than whites for all insurance types, with the exception of Medicaid. Our results suggest that equivalent insurance coverage may not ensure equal presentation of stage between African-American and white lung cancer patients. Future research is needed to determine whether other factors such as treatment delays, suboptimal preventive care, inappropriate specialist referral, community segregation, and a lack of patient trust in health care providers may explain the continuing racial disparities observed in the current study.
\end{abstract}

Keywords: Race; Lung cancer; Disparity; Diagnosis

\section{Introduction}

Lung cancer is the leading cause of cancer deaths in the United States, with mortality rates per 100,000 being higher among African-American (AA) (52.2) than white (49.2) patients (U.S. Cancer Statistics Working Group 2013; Elk and Landrine 2012). While a decline in lung cancer mortality has been observed in the general population, rates remain high in racial and ethnic minorities (Berger et al. 2007). Advanced stage at diagnosis is an important indicator of survival among lung cancer patients. AA lung cancer patients are more likely to be diagnosed at a later stage than whites (Schwartz et al. 2003; Hardy et al. 2009; Halpern et al. 2008). This disparity may be explained by racial differences in health insurance coverage wherein AAs are more likely to be underinsured or have no health insurance (Kirby and Kaneda 2010). Privately insured lung cancer patients

\footnotetext{
* Correspondence: jimmy.efird@stanfordalumni.org

${ }^{1}$ Center for Health Disparities, Brody School of Medicine, East Carolina

University, Greenville, NC 27834, USA

${ }^{2}$ Leo Jenkins Cancer Center, Brody School of Medicine, East Carolina

University, Greenville, NC, USA

Full list of author information is available at the end of the article
}

have been shown to survive longer than those with Medicaid or no insurance (Biswas et al. 2014). Furthermore, AA patients are less likely to receive preventive cancer services, education, and appropriate specialist referral, and are more likely to experience treatment delays (Felix-Aaron et al. 2005; Esnaola et al. 2008; Bach et al. 1999; Neighbors et al. 2007; Hershman et al. 2009).

In general, cancer patients diagnosed at a later stage have poorer survival than those diagnosed at earlier stages (e.g., 5 -year survival rate of $4 \%$ among patients diagnosed with late-stage disease compared with 54\% among patients diagnosed with early-stage disease (Ward et al. 2010; American Cancer Society 2014). Comparable stage at diagnosis between AA and white lung cancer patients has been observed within the U.S. Military Health System, a single payor system (Zheng et al. 2012; Mulligan et al. 2006). However, to our knowledge, no studies of lung cancer in a civilian population with multiple payors have examined stage of presentation by insurance type. The purpose of this study was to provide further insight into this unanswered question. We hypothesized that AAs, because of multiple historic determinants of poor health, 
would be diagnosed at a later stage than white lung cancer patients, regardless of insurance type.

\section{Results}

A total of 717 (31\%) AA and 1,634 (69\%) white lung cancer patients were treated at our center during the study period (Table 1). AA patients were more likely to be younger, male, and receive chemotherapy and radiation therapy. White patients were more likely to receive surgery. AA patients were more likely to have adenocarcinoma and non-small cell lung carcinoma not otherwise specified (NSCLC NOS), and less likely to have squamous cell carcinoma (SCC) and small cell lung carcinoma (SCLC) than whites.

Adjusting for age, sex, and smoking-related histology, AA patients had a marginally, but statistically significant increased risk $(\geq 14 \%)$ of being diagnosed at a later stage (III/IV versus I/II) than whites for all insurance types, with the exception of Medicaid (Table 2). An increasing trend across stage of presentation was observed among AA versus white lung cancer patients, when the data was stratified by age, sex, and smoking-related histology (Table 3). Furthermore, AAs presented with an increasing trend for later stage of lung cancer than whites for Medicare without supplement (adjusted $\mathrm{p}=0.015$ ), Medicare with supplement (adjusted p-for-trend $=0.016$ ), and no insurance/ self-pay (adjusted $\mathrm{p}$-for-trend $=0.049)($ Table 4$)$.

\section{Discussion}

Our results support previously published findings that AA lung cancer patients are more likely to be diagnosed at a later stage than whites (Yang et al. 2010; Schwartz et al. 2003; Hardy et al. 2009; Halpern et al. 2008). Additionally, it is uniquely shown that AA lung cancer patients with similar insurance coverage were diagnosed with more advanced disease than whites, except for Medicaid patients. This finding suggests that equivalent insurance coverage may not ensure equal presentation of stage between AA and white lung cancer patients.

The impact of race on stage at diagnosis may be related to factors other than insurance type in the current study. For example, social exclusion and provider mistrust may affect health outcomes for AA patients regardless of socioeconomic position (Carpenter et al. 2009; Hausmann et al. 2008; Williams and Jackson 2005). Other factors such as socioeconomic status (SES), residential segregation, and area-level SES also have been shown to contribute to lung cancer prevalence rates, stage at diagnosis, quality of care, and survival rates (Bennett et al. 1998; Hayanga et al. 2013; Landrine et al. 2012; Smith et al. 2012; Hao et al. 2011b, a). However, the extent to which racial differences in stage at diagnosis of lung cancer patients is attributable to the above
Table 1 Patient characteristics $(\mathrm{N}=\mathbf{2 , 3 5 1 )}$

\begin{tabular}{|c|c|c|c|}
\hline Patient characteristics & White $\mathrm{n}(\%)$ & AA n (\%) & P-value ${ }^{\dagger}$ \\
\hline Overall & $1,634(70)$ & $717(31)$ & - \\
\hline \multicolumn{4}{|l|}{ Age (years) } \\
\hline Mean $\pm S D$, Median (IQR) & $67 \pm 10,68(14)$ & $64 \pm 10,64(14)$ & $<0.0001$ \\
\hline \multicolumn{4}{|l|}{ Sex } \\
\hline Male & $981(60)$ & $491(68)$ & $<0.0001$ \\
\hline Female & $653(40)$ & $226(32)$ & \\
\hline \multicolumn{4}{|l|}{ Histology } \\
\hline Higher smoking risk & $718(44)$ & $260(36)$ & 0.0005 \\
\hline SCC & $514(31)$ & $207(29)$ & \\
\hline SCLC & $204(12)$ & $53(7)$ & \\
\hline Lower smoking risk & $916(56)$ & $457(64)$ & \\
\hline Adenocarcinoma & $461(28)$ & $236(33)$ & \\
\hline LCNEC & $54(3)$ & $21(3)$ & \\
\hline Bronchoalveolar & $32(2)$ & $13(2)$ & \\
\hline NSCLC NOS & $324(20)$ & $177(25)$ & \\
\hline Other & $45(3)$ & $10(1)$ & \\
\hline \multicolumn{4}{|l|}{ Tobacco use } \\
\hline Never & $139(9)$ & $58(8)$ & 0.81 \\
\hline Ever & $1,495(91)$ & $659(92)$ & \\
\hline \multicolumn{4}{|l|}{ Surgery } \\
\hline No & $1,066(65)$ & $549(77)$ & $<0.0001$ \\
\hline Yes & $568(35)$ & $168(23)$ & \\
\hline \multicolumn{4}{|l|}{ Chemotherapy } \\
\hline No & $920(56)$ & $369(51)$ & 0.031 \\
\hline Yes & $714(44)$ & $348(49)$ & \\
\hline \multicolumn{4}{|l|}{ Radiation therapy } \\
\hline No & $984(60)$ & $391(55)$ & 0.011 \\
\hline Yes & $650(40)$ & $326(45)$ & \\
\hline \multicolumn{4}{|l|}{ Insurance type $\mathrm{f}^{\prime}$} \\
\hline Medicare w/o supplement & $424(26)$ & $283(39)$ & $<0.0001$ \\
\hline Medicare with supplement & $511(31)$ & $109(15)$ & \\
\hline Medicaid & $92(6)$ & $105(15)$ & \\
\hline Private insurance & $530(32)$ & $145(20)$ & \\
\hline No insurance/self-pay & $77(5)$ & $75(10)$ & \\
\hline
\end{tabular}

${ }^{\dagger}$ Fisher's Exact (categorical variables), Exact Deuchler-Wilcoxon (continuous variables). ${ }^{5}$ Cigarette, cigar, pipe, smokeless (snuff, chew).

${ }^{\ddagger}$ Missing values were imputed using the expectation-maximization algorithm ( $\mathrm{n}=10$ simulations).

'Fraction missing information (Tobacco Use $=0.019$; Insurance Type $=0.0098$ ). $\mathrm{AA}=$ African-American; $\mathrm{LCNEC}$ = large cell neuroendocrine carcinoma; NSCLC $\mathrm{NOS}=$ non-small-cell lung carcinoma not otherwise specified; $\mathrm{SCC}=$ squamous cell carcinoma; SCLC = small cell lung carcinoma; $\mathrm{SD}=$ standard deviation; $\mathrm{IQR}=$ Interquartile range.

social determinants, as well as health beliefs, knowledge and behavior, remains unclear.

In the current study, stage of presentation did not statistically differ between AA and white lung cancer patients with Medicaid coverage. Possibly, Medicaid represents a 
Table 2 Relative risk of an AA patient presenting with Stage III/IV lung cancer by insurance type $(\mathrm{N}=2,351)$

\begin{tabular}{|c|c|c|c|c|c|}
\hline \multirow{3}{*}{$\begin{array}{l}\text { Type of health } \\
\text { insurance }\end{array}$} & \multicolumn{2}{|c|}{ Stages } & \multicolumn{3}{|c|}{ Relative risk $(95 \% \mathrm{Cl})$} \\
\hline & III/IV & $\mathrm{I} / \mathrm{II}$ & Unadjusted $^{\dagger}$ & Adjusted model $1^{\dagger ¥}$ & Adjusted model $2^{\$}$ \\
\hline & n (\%) & n (\%) & & & \\
\hline \multicolumn{6}{|c|}{ All insurance types $(n=2,351)$} \\
\hline White & $976(65)$ & $658(77)$ & 1.0 Referent & 1.0 Referent & 1.0 Referent \\
\hline AA & $516(36)$ & $201(23)$ & $1.20(1.13-1.28) p<0.0001$ & $1.19(1.12-1.27) p<0.0001$ & $1.17(1.10-1.24) p<0.0001$ \\
\hline \multicolumn{6}{|c|}{ Medicare w/o supplement $(n=707)$} \\
\hline White & $248(56)$ & $176(66)$ & 1.0 Referent & 1.0 Referent & 1.0 Referent \\
\hline AA & $193(44)$ & $90(34)$ & $1.17(1.04-1.31) p=0.0077$ & $1.16(1.03-1.29) p=0.013$ & $1.15(1.02-1.28) p=0.018$ \\
\hline \multicolumn{6}{|c|}{ Medicare with supplement $(n=620)$} \\
\hline White & $296(79)$ & $215(87)$ & 1.0 Referent & 1.0 Referent & 1.0 Referent \\
\hline AA & $77(21)$ & $32(13)$ & $1.22(1.06-1.41) p=0.0061$ & $1.22(1.05-1.40) p=0.0073$ & $1.21(1.05-1.40) p=0.010$ \\
\hline \multicolumn{6}{|c|}{ Medicaid $(n=197)$} \\
\hline White & $59(44)$ & $33(53)$ & 1.0 Referent & 1.0 Referent & 1.0 Referent \\
\hline AA & $76(56)$ & $29(47)$ & $1.13(0.93-1.37) p=0.22$ & $1.12(0.92-1.36) p=0.24$ & $1.14(0.94-1.37) p=0.19$ \\
\hline \multicolumn{6}{|c|}{ Private insurance $(n=675)$} \\
\hline White & $313(76)$ & $217(83)$ & 1.0 Referent & 1.0 Referent & 1.0 Referent \\
\hline AA & $101(24)$ & $44(17)$ & $1.18(1.04-1.34) p=0.012$ & $1.16(1.02-1.32) p=0.024$ & $1.14(1.005-1.30) p=0.042$ \\
\hline \multicolumn{6}{|c|}{ No insurance/self-pay $(n=152)$} \\
\hline White & $60(47)$ & $17(74)$ & 1.0 Referent & 1.0 Referent & 1.0 Referent \\
\hline AA & $69(53)$ & $6(26)$ & $1.18(1.03-1.35) p=0.017$ & $1.16(1.0007-1.33) p=0.040$ & $1.15(1.006-1.32) p=0.041$ \\
\hline
\end{tabular}

${ }^{\dagger}$ Relative risk and 95\% confidence intervals $(\mathrm{Cl})$ computed using Poisson regression with robust variance estimation.

${ }^{¥}$ Adjusted for sex and smoking-related histology.

^Adjusted for age (continuous), sex and smoking-related histology.

$\mathrm{AA}=$ African-American.

population in which outcomes are equalized regardless of race. Medicaid patients presumably have low SES and equally poor access to care due to low provider acceptance of this plan (Forrest et al. 2007). In contrast, patients who did not have health insurance may reflect a marginally higher socioeconomic position (e.g., working poor) closer to non-Medicaid coverage. Alternatively, this finding may represent an unexplained paradox, specific to our patient population, or chance.

Our findings support earlier research demonstrating that AA lung cancer patients are less likely to receive surgery for their disease compared with whites (Bach et al. 1999; Hardy et al. 2009; Yang et al. 2010; Said et al. 2010). A possible explanation for this finding is that AA patients are more likely to present with advanced disease that is not surgically treatable. In general, it is well known that minorities prioritize health to a lesser degree, postpone seeing a doctor, or do not have a regular physician, which may have contributed to the later stage at presentation observed in AA patients.

Lung cancer mortality rates per 100,000 in our region are consistently higher among male (89.6) and female (45.5) AAs than male (82.7) and female (35.7) whites (Rao and Knight 2008). We observed a similar trend for advanced stage malignancy upon presentation for both male and female AA patients. Furthermore, a statistically significant trend for later stage at presentation was observed by age of Medicare eligibility (i.e., $<65$ vs. $\geq 65$ ). While smoking causes all types of lung cancer, the percentage of cases attributable to smoking varies by histology, with squamous and small cell carcinomas conveying the greatest risk (Khuder 2001; Barbone et al. 1997; Boffetta et al. 2011). However, AAs in our study presented with more advanced stage lung cancer than whites, regardless of smoking-related histology.

Currently, no recommendations exist to effectively screen for lung cancer by race in the general population (Detterbeck et al. 2013; U.S. Preventive Services Task Force 2014; Aberle et al. 2013). The "fundamental cause of disease approach" argues that when no basic screening tool exists, racial differences in early detection and disease severity at presentation may be less pronounced (Kim et al. 2010). However, we observed that AA patients presented with more advanced stage lung cancer overall and within insurance type compared with whites. An effective screening tool, if it were to exist for AAs, likely would magnify this observed health disparity. Accordingly, AAs constitute a high-risk group who should be appropriately targeted for screening as new and effective technologies for identifying lung cancer are developed and made available (Gareen et al. 2014; Black et al. 2014). 
Table 3 Trend test for lung cancer stage of presentation by age, sex, smoking-related histology $(\mathrm{N}=2,351)$

\begin{tabular}{|c|c|c|c|c|c|c|c|}
\hline \multirow{2}{*}{$\begin{array}{c}\text { Patient } \\
\text { characteristics }\end{array}$} & \multicolumn{4}{|c|}{ Stage } & \multicolumn{3}{|c|}{ P-for-trend } \\
\hline & $\begin{array}{c}\text { I } \\
\text { n (\%) }\end{array}$ & $\begin{array}{c}\text { II } \\
\text { n (\%) }\end{array}$ & $\begin{array}{c}\text { III } \\
\text { n (\%) }\end{array}$ & $\begin{array}{c}\text { IV } \\
\text { n (\%) }\end{array}$ & Unadjusted $^{\dagger}$ & $\begin{array}{c}\text { Adjusted } \\
\text { model } \\
1^{\dagger *}\end{array}$ & $\begin{array}{l}\text { Adjusted } \\
\text { model } \\
2^{\S, \$}\end{array}$ \\
\hline \multicolumn{5}{|l|}{ Males $(n=1,472)$} & $<0.0001$ & $<0.0001$ & 0.0005 \\
\hline White & $268(72)$ & $119(78)$ & $251(64)$ & $343(61)$ & & & \\
\hline AA & $102(28)$ & $33(22)$ & $139(36)$ & $217(39)$ & & & \\
\hline \multicolumn{5}{|l|}{ Females $(n=879)$} & 0.0009 & 0.0010 & 0.0030 \\
\hline White & $199(80)$ & $72(82)$ & $157(73)$ & $225(69)$ & & & \\
\hline AA & $50(20)$ & $16(18)$ & $57(27)$ & $103(31)$ & & & \\
\hline \multicolumn{5}{|l|}{ Age $<65(n=1,008)$} & 0.0040 & 0.0147 & 0.0140 \\
\hline White & $142(67)$ & $73(78)$ & $176(63)$ & $247(58)$ & & & \\
\hline AA & $69(33)$ & $21(22)$ & $104(37)$ & $176(42)$ & & & \\
\hline \multicolumn{5}{|l|}{ Age $\geq 65(n=1,343)$} & $<0.0001$ & 0.0001 & 0.0001 \\
\hline White & $325(80)$ & $118(81)$ & $232(72)$ & $321(69)$ & & & \\
\hline AA & $83(20)$ & $28(19)$ & $92(28)$ & $144(31)$ & & & \\
\hline \multicolumn{5}{|c|}{ Higher smoking risk $(n=978)^{\wedge}$} & 0.0013 & 0.0011 & 0.0015 \\
\hline White & $217(79)$ & $98(83)$ & $181(68)$ & $222(70)$ & & & \\
\hline AA & $58(21)$ & $20(17)$ & $85(32)$ & $97(30)$ & & & \\
\hline \multicolumn{5}{|c|}{ Lower smoking risk $(n=1,373)^{\circ}$} & $<0.0001$ & 0.0001 & 0.0011 \\
\hline White & $250(73)$ & $93(76)$ & $227(67)$ & $346(61)$ & & & \\
\hline $\mathrm{AA}$ & $94(27)$ & $29(24)$ & $111(33)$ & $223(39)$ & & & \\
\hline \multicolumn{8}{|c|}{$\begin{array}{l}\text { Squamous cell carcinoma, small cell lung carcinoma (SCLC). } \\
\text { "Adenocarcinoma, large cell neuroendocrine carcinoma (LCNEC), bronchoalveolar, non-small-cell lung carcinoma not otherwise specified (NSCLC NOS), other } \\
\text { histology. AA = African-American } \\
\text { †Exact Cochran-Armitage trend test. } \\
\text { sLikelihood ratio trend test. }\end{array}$} \\
\hline
\end{tabular}

This study has several strengths. A large AA population in eastern North Carolina allowed for us to report on a group that has experienced historic differences in access to care and discrimination. Ninety percent of the counties in this region have a higher percentage of AAs than the national value of $13.1 \%$ (United States Census Bureau 2010; Efird et al. 2013). Our rural catchment area represents a unique population regarding health care resources. For example, residents of rural regions have limited access to medical providers compared with urban areas (Shugarman and Farley 2003; Pathman et al. 2006). Data also were collected from a population-based cancer registry with a standardized data entry system and routine quality control.

This study was limited by the incompleteness of some variables ( $n=45$, tobacco use; $n=21$, payor status). However, the relative imputation efficiency for these variables exceeded $99.8 \%$ and it is unlikely that this would have biased our results. Important pieces of information that would have been useful in the etiologic and explanatory interpretation of the study findings (e.g., income, education and occupation, individual-level SES, marital status, evidence of doctor's or emergency room visits within the year prior to cancer diagnosis, percentage of patients with an $\mathrm{x}$-ray obtained within 6 months prior to diagnosis, pack years smoked, and age of first tobacco use) were not available in the current analysis. Ideally, future studies will be designed to collect this information.

Our analysis by insurance type and stage resulted in small sample sizes within groups. Insurance status was recorded at the time of diagnosis and it also is possible that Medicaid was retroactively granted to uninsured or underinsured patients as a result of diagnosis. The latter limitation may have resulted in misclassification and selection bias. Self-reports of tobacco use have been shown to be lower than actual use, especially among AA patients (Gorber et al. 2009; Corral et al. 2013; Fisher et al. 2008), and the tobacco products that AAs are more likely than whites to smoke (i.e., cigarillos) rarely are assessed (Corral et al. 2013). The reporting of tobacco use is a sensitive and potentially stigmatizing topic and some patients may have been reluctant to report usage truthfully. However, any resulting bias likely had a 
Table 4 Trend analysis for lung cancer stage of presentation by insurance type $(N=2,351)$

\begin{tabular}{|c|c|c|c|c|c|c|c|}
\hline \multirow{2}{*}{$\begin{array}{l}\text { Type of health } \\
\text { insurance }\end{array}$} & \multicolumn{4}{|c|}{ Stage } & \multicolumn{3}{|c|}{ P-for-trend } \\
\hline & $\begin{array}{c}\text { I } \\
\text { n (\%) }\end{array}$ & $\begin{array}{c}\text { II } \\
\text { n (\%) }\end{array}$ & $\begin{array}{c}\text { III } \\
\text { n (\%) }\end{array}$ & $\begin{array}{c}\text { IV } \\
\text { n (\%) }\end{array}$ & Unadjusted $^{\dagger}$ & $\begin{array}{c}\text { Adjusted } \\
\text { model } \\
1^{\dagger ¥} \\
\end{array}$ & $\begin{array}{c}\text { Adjusted } \\
\text { model } \\
2^{\$ \S}\end{array}$ \\
\hline \multicolumn{5}{|c|}{ All insurance types } & $<0.0001$ & $<0.0001$ & $<0.0001$ \\
\hline White & $467(75)$ & $191(80)$ & $408(68)$ & $568(64)$ & & & \\
\hline AA & $152(25)$ & $49(20)$ & $196(32)$ & $320(36)$ & & & \\
\hline \multicolumn{5}{|c|}{ Medicare w/o supplement } & 0.0079 & 0.014 & 0.015 \\
\hline White & $129(67)$ & $47(64)$ & $107(58)$ & $141(55)$ & & & \\
\hline AA & $64(33)$ & $26(36)$ & $78(42)$ & $115(45)$ & & & \\
\hline \multicolumn{5}{|c|}{ Medicare with supplement } & 0.011 & 0.013 & 0.016 \\
\hline White & $156(88)$ & $59(84)$ & $118(80)$ & $178(79)$ & & & \\
\hline AA & $21(12)$ & $11(16)$ & $29(20)$ & $48(21)$ & & & \\
\hline \multicolumn{5}{|l|}{ Medicaid } & 0.48 & 0.55 & 0.44 \\
\hline White & $22(48)$ & $11(69)$ & $19(41)$ & $40(45)$ & & & \\
\hline AA & $24(52)$ & $5(31)$ & $27(59)$ & $49(55)$ & & & \\
\hline \multicolumn{5}{|l|}{ Private insurance } & 0.049 & 0.10 & 0.14 \\
\hline White & $149(80)$ & $68(92)$ & $139(78)$ & $174(74)$ & & & \\
\hline AA & $38(20)$ & $6(8)$ & $39(22)$ & $62(22)$ & & & \\
\hline \multicolumn{5}{|c|}{ No insurance/self-pay } & 0.016 & 0.047 & 0.049 \\
\hline White & $11(69)$ & $6(86)$ & $25(52)$ & 35 (43) & & & \\
\hline AA & $5(31)$ & $1(14)$ & $23(48)$ & $46(57)$ & & & \\
\hline
\end{tabular}

${ }^{\dagger}$ Exact Cochran-Armitage trend test.

$\S$ Likelihood ratio trend test.

${ }^{¥}$ Adjusted for sex and smoking-related histology.

^Adjusted for age (continuous), sex and smoking-related histology.

$\mathrm{AA}=$ African-American.

nominal impact on our results since the vast majority of lung cancer patients have a history of tobacco use. The absence of individual and area-level socioeconomic measures was another potential limitation of our analyses.

The results of this study are from a rural region with a unique population and may not generalize to other areas of the country. However, because our data were collected from one health system, this might have partially controlled for other healthcare-related factors (e.g., variation in misclassification of staging system and payor status, as well as geography). Furthermore, we were unable to reliably estimate socioeconomic position using zip codes because a large percentage of patients in our region have postal box addresses. However, eastern North Carolina is relatively homogenous with respect to socioeconomic status and it is unlikely that inclusion of this variable in our models would have substantively changed the results of this study.

\section{Conclusions}

Equality in health insurance (a crude measure of access to care) may not ensure equal presentation of stage between AA and white lung cancer patients. Further research is needed to identify the underlying determinants and appropriate measures for ameliorating this disparity.

\section{Methods}

\section{Patients and clinical variables}

Patients who were diagnosed with lung cancer between 2001 and 2010 at the Leo Jenkins Cancer Center, East Carolina University were included in this study. Approval for the study was obtained from the Institutional Review Board at the Brody School of Medicine.

Methodology for data collection has been previously described (Biswas et al. 2014; Elchoufani et al. 2013). Briefly, data were obtained from the Vidant Medical Center Cancer Registry, which includes patients seen at Vidant Medical Center, Brody School of Medicine, Physicians East, SurgiCenter, and other local medical clinics. The registry follows standard data collection and validation procedures and has received the Commission on Cancer Outstanding Achievement Award from the American College of Surgeons. When necessary, information in our tumor registry was verified by cross-linkage with administrative billing records. 
Our analysis data set included information on age, sex, race, stage, histology, tobacco use, and treatment history (surgery, chemotherapy, and radiation therapy according to current standards of practice). Lung cancer was categorized into 7 groups based on pathology reports and included SCC, adenocarcinoma, NSCLC NOS, SCLC, large cell neuroendocrine carcinoma (LCNEC), bronchoalveolar carcinoma, and other histology. Histology was stratified by high (SCC, SCLC) and low (adenocarcinoma, LCNEC, bronchoalveolar, NSCLC NOS, other) smoking risk (Khuder 2001; Barbone et al. 1997; Boffetta et al. 2011). Tumor stage at initial diagnosis/presentation was categorized according to criteria established by the American Joint Committee on Cancer (AJCC). Health insurance coverage was determined at the time of diagnosis and defined as Medicare with and without supplement, Medicaid, private, and no insurance/self-pay. Insurance was coded as a single variable field. Individuals with Medicare may have had supplemental insurance, and this was coded as a separate category from Medicare without supplement. Because of small numbers, patients with TriCare $(n=26)$ or Veteran's Affairs insurance $(n=3)$ were recoded as private insurance and Medicare without supplement, respectively. Tobacco use was self-reported and included cigarette, cigar, pipe, and smokeless tobacco (snuff, chew) use. Similarly, information on age, sex, and race was provided by the patient.

\section{Statistical analysis}

Categorical variables were reported as frequency and percentage while continuous variables were reported as mean, \pm standard deviation, median, and interquartile range. Statistical significance for categorical variables was tested using the Fisher's exact test and the Deuchler-Wilcoxon procedure for continuous variables. Relative risks with 95\% confidence intervals $(\mathrm{CI})$ were used as the measure of association between predictor variables and stage at presentation (III/IV versus I/II) and were computed using a robust Poisson regression model. Trend across levels of stage by race was assessed using the exact CochranArmitage or likelihood ratio test for trend.

An iterative expectation-maximization (EM) algorithm was used to impute missing values (Dempster et al. 1977; Little et al. 2012; Ware et al. 2012). The relative efficiency for each imputed variable (tobacco use, insurance type) exceeded 99.8\%. Model goodness of fit was assessed using the Hosmer-Lemeshow test (Hosmer and Lemeshow 2000). Rounding was performed using the method of Holly and Whittemore (Holly et al. 1989). Statistical significance was defined as $\mathrm{p}<0.05$. SAS Version 9.4 (Cary, NC) was used for all analyses.

\section{Abbreviations}

AA: African-American; AJCC: American Joint Committee on Cancer;

$\mathrm{Cl}$ : Confidence intervals; EM: Expectation-maximization; IQR: Interquartile range;
LCNEC: Large cell neuroendocrine carcinoma; NSCLC NOS: Non-small cell lung carcinoma not otherwise specified; RR: Relative risk; SCLC: Small cell lung carcinoma; SD: Standard deviation; SES: Socioeconomic status; SCC: Squamous cell carcinoma.

\section{Competing interests}

The authors declare no competing interests in the writing of this manuscript.

\section{Authors' contributions}

All authors contributed to the interpretation of data and the overall intellectual content on the paper, and drafting and editing of the manuscript. JTE, KYS, and TB contributed to the study design and data collection. JTE and KYS contributed to data analysis. All authors read and approved the final manuscript.

\section{Acknowledgments}

The authors would like to thank Drs. Katherine Jones (Brody School of Medicine) and Faith Davis (University of Alberta) for insightful comments and advice during the writing of the manuscript.

\section{Author details}

${ }^{1}$ Center for Health Disparities, Brody School of Medicine, East Carolina University, Greenville, NC 27834, USA. ${ }^{2}$ Leo Jenkins Cancer Center, Brody School of Medicine, East Carolina University, Greenville, NC, USA.

${ }^{3}$ Department of Internal Medicine, Wake Forest University School of Medicine, Winston-Salem, NC, USA. ${ }^{4}$ Department of Radiation Oncology, Seidman Cancer Center, Case Western Reserve University School of Medicine, Cleveland, OH, USA. ${ }^{5}$ Department of Radiation Oncology, Lineberger Comprehensive Cancer Center, University of North Carolina at Chapel Hill, Chapel Hill, NC, USA.

Received: 4 July 2014 Accepted: 26 November 2014 Published: 3 December 2014

\section{References}

Aberle DR, Abtin F, Brown K (2013) Computed tomography screening for lung cancer: has it finally arrived? Implications of the National Lung Screening Trial. J Clin Oncol 31:1002-1008

American Cancer Society (2014) Cancer Treatment and Survivorship Facts \& Figures 2014-2015. American Cancer Society, Atlanta, GA, Retrieved December 2, 2014, from http://www.cancer.org/acs/groups/content/ @research/documents/document/acspc-042801.pdf

Bach PB, Cramer LD, Warren JL, Begg CB (1999) Racial differences in the treatment of early-stage lung cancer. N Engl J Med 341(16):1198-1205, do:10.1056/NEJM199910143411606

Barbone F, Bovenzi M, Cavallieri F, Stanta G (1997) Cigarette smoking and histologic type of lung cancer in men. Chest 112(6):1474-1479

Bennett CL, Ferreira MR, Davis TC, Kaplan J, Weinberger M, Kuzel T, Seday MA, Sartor O (1998) Relation between literacy, race, and stage of presentation among low-income patients with prostate cancer. J Clin Oncol 16(9):3101-3104

Berger M, Lund MJ, Brawley OW (2007) Racial disparities in lung cancer. Curr Probl Cancer 31(3):202-210

Biswas T, Walker P, Podder T, Rosenman J, Efird JT (2014) Important prognostic factors for lung cancer in tobacco predominant Eastern North Carolina: a study based on a single cancer registry. Lung Cancer 84(2):116-120

Black WC, Gareen IF, Soneji SS, Sicks JD, Keeler EB, Aberle DR, Naeim A, Church TR, Silvestri GA, Gorelick J, Gatsonis C, for the National Lung Screening Trial Research Team (2014) Cost-effectiveness of CT screening in the National Lung Screening Trial. N Engl J Med 371:1793-1802

Boffetta P, Jayaprakash V, Yang P, Asomaning K, Muscat J, Schwartz AG, Zhang Z-F, Marchand LL, Cote ML, Stoddard SM, Morgenstern H, Hung RJ, Christiani DC (2011) Tobacco smoking as a risk factor of bronchioloalveolar carcinoma of the lung: pooled analysis of seven case-control studies in the International Lung Cancer Consortium (ILCCO). Cancer Causes Control 22(1):73-79

Carpenter WR, Godley PA, Clark JA, Talcott JA, Finnegan T, Mishel M, Bensen J, Rayford W, Su LJ, Fontham ET, Mohler JL (2009) Racial differences in trust and regular source of patient care and the implications for prostate cancer screening use. Cancer 115(21):5048-5059, doi:10.1002/cncr.24539

Corral I, Landrine H, Simms DA, Bess JJ (2013) Polytobacco use and multipleproduct smoking among a random community sample of African-American adults. BMJ Open 3(12):e003606 
Dempster AP, Laird NM, Rubin DB (1977) Maximum likelihood from incomplete data via the EM algorithm. J R Stat Soc Ser B Stat Methodol 39(1):1-38

Detterbeck FC, Mazzone PJ, Naidich DP, Bach PB (2013) Screening for Lung Cancer: Diagnosis and Management of Lung Cancer, 3rd ed: American College of Chest Physicians Evidence-Based Clinical Practice Guidelines. Chest 143(5 Suppl):e78S-e92S, doi:10.1378/chest. 12-2350

Efird JT, O'Neal WT, Anderson CA, O'Neal JB, Kindell LC, Ferguson TB, Chitwood WR, Kypson AP (2013) The effect of race and chronic obstructive pulmonary disease on long-term survival after coronary artery bypass grafting. Front Public Health 1(4):1-7, doi:10.3389/fpubh.2013.00004

Elchoufani SE, Efird JT, O'Neal JB, Davies SW, Landrine H, Biswas T (2013) The relation of race and type of health insurance to long-term risk of mortality among lung cancer patients in rural Eastern North Carolina. N C Med J 74(6):464-469

Elk R, Landrine H (2012) Cancer Disparities: Causes and Evidence-Based Solutions. Springer, New York, NY

Esnaola NF, Gebregziabher M, Knott K, Finney C, Silvestri GA, Reed CE, Ford ME (2008) Underuse of surgical resection for localized, non-small cell lung cancer among whites and African Americans in South Carolina. Ann Thorac Surg 86(1):220-226, doi:10.1016/j.athoracsur.2008.02.072

Felix-Aaron K, Moy E, Kang M, Patel M, Chesley FD, Clancy C (2005) Variation in quality of men's health care by race/ethnicity and social class. Med Care 43(3 Suppl):172-181

Fisher MA, Taylor GW, Shelton BJ, Debanne S (2008) Age and race/ethnicitygender predictors of denying smoking, United States. J Health Care Poor Underserved 19(1):75-89

Forrest CB, Shadmi E, Nutting PA, Starfield B (2007) Specialty referral completion among primary care patients: results from the ASPN Referral Study. Ann Fam Med 5(4):361-367, doi:10.1370/afm.703

Gareen IF, Duan F, Greco EM, Snyder BS, Boiselle PM, Park ER, Fryback D, Gatsonis C (2014) Impact of lung cancer screening results on participant healthrelated quality of life and state of anxiety in the National Lung Screening Trial. Cancer 120:3401-3409

Gorber CS, Schofield-Hurwitz S, Hardt J, Levasseur G, Tremblay M (2009) The accuracy of self-reported smoking: a systematic review of the relationship between self-reported and cotinine-assessed smoking status. Nicotine Tob Res 11(1):12-24

Halpern MT, Ward EM, Pavluck AL, Schrag NM, Bian J, Chen AY (2008) Association of insurance status and ethnicity with cancer stage at disagnosis for 12 cancer sites: a retrospective analysis. Lancet Oncol 9:222-232

Hao Y, Landrine H, Jemal A, Ward KC, Bayakly AR, Young JLJ, Flanders WD, Ward EM (2011a) Race, neighbourhood characteristics and disparities in chemotherapy for colorectal cancer. J Epidemiol Community Health 65(3):211-217

Hao Y, Landrine H, Smith T, Kaw C, Corral I, Stein K (201 1b) Residential segregation and disparities in health-related quality of life among Black and White cancer survivors. Health Psychol 30(2):137-144

Hardy D, Liu CC, Xia R, Cormier JN, Chan W, White A, Burau K, Du XL (2009) Racial disparities and treatment trends in a large cohort of elderly black and white patients with nonsmall cell lung cancer. Cancer 115(10):2199-2211, doi:10.1002/cncr.24248

Hausmann LR, Jeong K, Bost JE, Ibrahim SA (2008) Perceived discrimination in health care and health status in a racially diverse sample. Med Care 46(9):905-914, doi:10.1097/MLR.0b013e3181792562

Hayanga AJ, Zeliadt SB, Backhus LM (2013) Residential segregation and lung cancer mortality in the United States. JAMA Surg 148(1):37-42, doi:10.1001/jamasurgery.2013.408

Hershman DL, Unger JM, Barlow WE, Hutchins LF, Martino S, Osborne CK, Livingston RB, Albain KS (2009) Treatment quality and outcomes of African American versus white breast cancer patients: retrospective analysis of Southwest Oncology studies S8814/S8897. J Clin Oncol 27(13):2157-2162, doi:10.1200/JCO.2008.19.1163

Holly EA, Whittemore AS, Aston DA, Ahn DK, Nickoloff BJ, Kristiansen JJ (1989) Anal cancer incidence: genital warts, anal fissure or fistula, hemorrhoids, and smoking. J Natl Cancer Inst 81:1726-1731

Hosmer DW, Lemeshow S (2000) Applied Logistic Regression. Wiley, New York

Khuder SA (2001) Effect of cigarette smoking on major histological types of lung cancer: a meta-analysis. Lung Cancer 31(2-3):139-148

Kim S, Dolecek TA, Davis FG (2010) Racial differences in stage at diagnosis and survival from epithelial ovarian cancer: a fundamental cause of disease approach. Soc Sci Med 71(2):274-281, doi:10.1016/j.socscimed.2010.03.033
Kirby JB, Kaneda T (2010) Unhealthy and uninsured: exploring racial differences in health and health insurance coverage using a life table approach. Demography 47(4):1035-1051, doi:10.1007/BF03213738

Landrine H, Corral I, Hao Y, Kaw C, King J, Fondren J (2012) Cancer geography: the role of neighborhoods in cancer and cancer disparities. In: Elk R, Landrine H (eds) Cancer Disparities. Springer, New York, NY, pp 141-166

Little RJ, D'Agostino R, Cohen ML, Dickersin K, Emerson SS, Farrar JT, Frangakis C, Hogan JW, Molenberghs G, Murphy SA, Neaton JD, Rotnitzky A, Scharfstein D, Shih WJ, Siegel JP, Stern H (2012) The prevention and treatment of missing data in clinical trials. N Engl J Med 367(14):1355-1360, doi:10.1056/NEJMsr1203730

Mulligan CR, Meram AD, Proctor CD, Wu H, Zhu K, Marrogi AJ (2006) Unlimited access to care: effect on racial disparity and prognostic factors in lung cancer. Cancer Epidemiol Biomarkers Prev 15(1):25-31, doi:10.1158/10559965.EPI-05-0537

Neighbors CJ, Rogers ML, Shenassa ED, Sciamanna CN, Clark MA, Novak SP (2007) Ethnic/racial disparities in hospital procedure volume for lung resection for lung cancer. Med Care 45(7):655-663, doi:10.1097/MLR.0b013e3180326110

Pathman DE, Ricketts TC 3rd, Konrad TR (2006) How adults' access to outpatient physician services relates to the local supply of primary care physicians in the rural southeast. Health Serv Res 41(1):79-102, doi:10.1111/j.14756773.2005.00454.x

Rao C, Knight K (2008) Running the numbers - cancer incidence and mortality trends in north carolina. N C Med J 69(4):327-334

Said R, Terjanian T, Taioli E (2010) Clinical characteristics and presentation of lung cancer according to race and place of birth. Future Oncol 6(8):1353-1361, doi:10.2217/fon. 10.89

Schwartz KL, Crossley-May H, Vigneau FD, Brown K, Banerjee M (2003) Race, socioeconomic status and stage at diagnosis for five common malignancies. Cancer Causes Control 14(8):761-766

Shugarman LR, Farley DO (2003) Shortcomings in Medicare bonus payments for physicians in underserved areas. Health Aff (Millwood) 22(4):173-178

Smith T, Stein K, Kim Y, Cooper D, Virgo K, Corral I, Landrine H (2012) Racial, ethnic, and socioeconomic health disparities among cancer survivors and informal caregivers. In: Elk R, Landrine H (eds) Cancer Disparities. Springer, New York, NY, pp 121-140

U.S. Cancer Statistics Working Group (2013) United States Cancer Statistics: 1999-2009 Incidence and Mortality Web-based Report. Centers for Disease Control and Prevention, Atlanta, GA, Retrieved December 2, 2014, from http://www.cdc.gov/uscs

U.S. Preventive Services Task Force (2014) Screening for Lung Cancer. USPSTF Program Office, Rockville, MD, Retrieved November 2, 2014, from http:// www.uspreventiveservicestaskforce.org/uspstf/uspslung.htm

United States Census Bureau (2010) State \& County Quick Facts. U.S. Department of Commerce, Washington, DC, Retrieved December 2, 2014, from http:// quickfacts.census.gov/qfd/index.html

Ward EM, Fedewa SA, Cokkinides V, Virgo K (2010) The association of insurance and stage at diagnosis among patients aged 55 to 74 years in the national cancer database. Cancer J 16(6):614-621, doi:10.1097/PPO.0b013e3181ff2aec

Ware JH, Harrington D, Hunter DJ, D'Agostino R (2012) Missing data. N Engl J Med 367(14):1353-1354

Williams DR, Jackson PB (2005) Social sources of racial disparities in health. Health Aff (Millwood) 24(2):325-334, doi:10.1377/hlthaff.24.2.325

Yang R, Cheung MC, Byrne MM, Huang Y, Nguyen D, Lally BE, Koniaris LG (2010) Do racial or socioeconomic disparities exist in lung cancer treatment? Cancer 116(10):2437-2447, doi:10.1002/cncr.24986

Zheng L, Enewold L, Zahm SH, Shriver CD, Zhou J, Marrogi A, McGlynn KA, Zhu K (2012) Lung cancer survival among black and white patients in an equal access health system. Cancer Epidemiol Biomarkers Prev 21(10):1841-1847, doi:10.1158/1055-9965.EPI-12-0560

doi:10.1186/2193-1801-3-710

Cite this article as: Efird et al:: Race, insurance type, and stage of presentation among lung cancer patients. SpringerPlus 2014 3:710 